\title{
Characterization of organic-rich mineral debris revealed by rapid glacier retreat, Indren Glacier, European Alps
}

\author{
FREPPAZ Michele ${ }^{1,2}$ (D) https://orcid.org/oooo-0oo2-4290-6850; e-mail: michele.freppaz@unito.it \\ WILLIAMS Mark W.3 iD https://orcid.org/oooo-ooo2-9439-8480; e-mail: markw@snobear.colorado.edu \\ GABRIELI Jacopo4 ${ }^{\text {iD }}$ https://orcid.org/oooo-0oo1-6230-5668; e-mail: gabrieli@unive.it \\ GORRA Roberta1 ${ }^{\text {iD }}$ https://orcid.org/oooo-0002-7007-7113; e-mail: roberta.gorra@unito.it

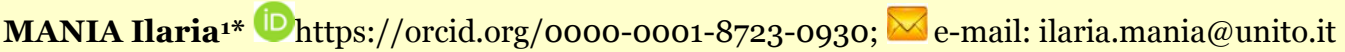 \\ ASCHER-JENULL Judith5 iD https://orcid.org/oooo-0003-0127-8058; e-mail:judith.ascher@uibk.ac.at \\ EGLI Markus6 ${ }^{\text {DD }}$ https://orcid.org/oooo-0002-1528-3440; e-mail: markus.egli@geo.uzh.ch \\ CELI Luisella1 ${ }^{\text {iD }}$ https://orcid.org/oooo-0oo2-2365-3317; e-mail: luisella.celi@unito.it \\ ${ }^{*}$ Corresponding author \\ 1 Department of Agriculture, Forest and Food Sciences, University of Turin, Largo Paolo Braccini 2, 10095 Grugliasco \\ (TO), Italy \\ 2 NatRisk Research Centre on Natural Risks in Mountain and Hilly Environments, University of Turin, Largo Paolo \\ Braccini 2, 10095 Grugliasco (TO), Italy \\ 3 Institute of Arctic and Alpine Research and Department of Geography, University of Colorado at Boulder, UCB 45O, \\ Boulder, CO 80309, USA \\ 4 CNR-ISP (Consiglio Nazionale delle Ricerche, Istituto di Scienze Polari), via Torino 155, 30172 Venezia-Mestre, Italy \\ 5 Institute of Microbiology, University of Innsbruck, Technikerstraße 25, 6020 Innsbruck, Austria \\ 6 Department of Geography, University of Zurich, Winterthurerstrasse 190, 8057 Zurich, Switzerland
}

Citation: Freppaz M, Williams MW, Gabrieli J, et al. (2021) Characterization of organic-rich mineral debris revealed by rapid glacier retreat, Indren Glacier, European Alps. Journal of Mountain Science 18(6). https://doi.org/10.1007/s11629o20-6288-8

(C) The Author(s) 2021

\begin{abstract}
In the summer of 2003 and 2004, characterized by a rapid glacier retreat, a stony surface covered by well-structured organic-rich mineral debris was observed very close to the Indren glacier terminus (Monte Rosa Massif, NW Italy, 3100 $\mathrm{m}$ ASL), on an area covered by the glacier tongue till the year before. The origin and type of this organicrich material were investigated, in order to detect their characteristics, potential sources and fate within
\end{abstract}

Received: 25-Jun-2020

Revised: 22-Feb-2021

Accepted: 06-May-2021 the foreland system. The deposits were dated using Carbon-14 and analyzed for the chemical characteristics of the organic component, the elemental composition of the mineral fraction and presence of microbial markers. The material, granular and dark in color, had a total organic carbon (TOC) content ranging between $17.4 \pm 0.39$ and $28.1 \pm 0.63 \mathrm{~g}$ $\mathrm{kg}^{-1}$ dry weight (dw), significantly higher than the surrounding glacial till $\left(\sim 1.4 \mathrm{~g} \mathrm{~kg}^{-1} \mathrm{dw}\right)$, although only $0.33 \%$ of it was in water soluble form. Microbial carbon $(\mathrm{C})$ and nitrogen $(\mathrm{N})$ accounted for $10.6 \%$ and $3.13 \%$ of TOC and total N, respectively. Dissolved 
nitrogen (N), mainly present as ammonium, represented $2.40 \%$ of the total $\mathrm{N}$. The low aromatic component and large presence of nitrogen (N)derived compounds suggested that most of the organic carbon (OC) in these organic-rich mineral deposits was derived from microbial cells, although the high average radiocarbon age of about 2900 years may also point to the contribution of aeolian depositions of anthropogenic or natural origin. Elemental composition and the crustal enrichment factor of trace elements in the mineral fraction of the aggregates corroborated the hypothesis that most part of the accumulated material derived from ice meltwater. Some indicators of the colonization of these deposits by microbial communities were also reported, from the abundance of DNA and phylogenetic markers, to the presence of bacterial taxa commonly able to thrive in similar habitats. All these elements suggested that such kind of deposits may have a potential role as energy and nutrient sources in recently deglaciated areas, highlighting the necessity to better understand the processes underlying their formation and their evolution.

Keywords: Glacier foreland; Dissolved organic carbon; Organic matter; qPCR; Microbial community; Trace elements

\section{Introduction}

Many alpine areas are experiencing numerous changes that affect biogeochemical cycling, including increase in air temperature and deglaciation, along with changes in the quality of atmospheric deposition in wetfall and dryfall (Fountain et al. 2012; Mladenov et al. 2012). The direct response of glaciers to climate change occurs through changes in their mass balance and ultimately in variations in glacier length and size (Hoelzle et al. 2003; Haeberli et al. 2004). As glaciers undergo negative mass balance that give rise to retreat, new areas become ice-free.

The newly deglaciated areas - often called glacier forefields - are then subjected to changes in mineral weathering, biogeochemical cycling, and soil formation processes (Dümig et al. 2011; D'Amico et al. 2014, 2015). The first evidence is a high rate of microbial activity (Schulz et al. 2013; Bradley et al. 2014; Nikrad et al. 2016), within a few years of deglaciation in some cases (Schmidt et al. 2009; Schurig et al. 2013). In spite of this, these environments are severely nutrient-limited (Williams et al. 1997, 2007; Brooks and Williams 1999; King et al. 2008). Thus, there is some urgency to understand the sources, transport and fate of nutrients to highelevation areas undergoing rapid environmental change (Ren et al. 2019; Wadham et al. 2019).

Glaciers themselves can be sources of organic carbon (OC) and nutrients, exported through glacial meltwaters to glacier forefields (Bradley et al. 2014; Hood et al. 2015; Li et al. 2018). Ice sheet surfaces, including ecosystems such as cryoconite holes, have been demonstrated to host active microbial communities, including primary producers but also organisms involved in nutrient cycling (Anesio and Laybourn-Parry 2012; Margesin and Collins 2019). For instance, Anesio et al. (2009) reported that on a global basis (all glaciers outside of Antarctica) cryoconite holes have the potential to fix as much as $64 \mathrm{Gg} \mathrm{C} \mathrm{yr}^{-1}$. Furthermore, several studies pointed out that glacier surfaces can accumulate aeolian depositions and anthropogenic aerosols, acting as a reservoir of allochthonous minerals and OC (Jenk et al. 2006; Stubbins et al. 2012). "Saharan" dust storms are ubiquitous in the European Alps, and Mladenov et al. $(2009,2010,2011)$ reported that aeolian deposition from such Saharan dust storms were surprisingly comprised of about $10 \%$ to $20 \%$ OC in the Sierra Nevada of Spain.

Another potential source of carbon and nutrients is the subglacial environment, as a result of different processes including microbial chemolithoautotrophic growth and rock weathering (Wadham et al. 2010; Boyd et al. 2014), but also the recycling of ancient, buried organic matter (Barker et al. 2018).

As a glacier melts, the export of glacially derived dissolved organic carbon (DOC) may increase in response to climate warming, and the effects of this organic material on downstream environments may become increasingly important for plant colonization (Dubnick et al. 2010). Several reports have shown that a high proportion of the DOC present in glacial runoff is labile (Lafrenière and Sharp 2004; Barker et al. 2006, 2009; Hood et al. 2009; Dubnick et al. 2017) and may undergo the degradation and mineralization processes, which are the base for biological colonization.

Europe has experienced a pronounced summer warming over the 1986-2015 period, with an increase of severe heat wave events, one of the most impressive occurring in 2003 (Luterbacher et al. 2004, 2016). The impact of the 2003 summer heatwave on alpine 
glaciers resulted in outstanding negative mass balances and records in the amount of meltwater discharge from these glaciers (e.g. Beniston 2004). In particular, the Indren Glacier in the northwestern Alps in Italy retreated $9 \mathrm{~m}$ in 2003 (Armando 2004). This glacial retreat revealed in the newly exposed glacier foreland the presence of mineral debris, consisting of black-colored material, with a granular structure.

The aim of this study was to characterize such mineral debris, potentially representing a common element in other alpine areas undergoing processes of rapid glacial retreat, in order to investigate their characteristics and to assess their origin and their possible fate within the foreland system. To answer these questions, we investigated the molecular and elemental composition of the deposits, their age and the abundance and diversity of microbial markers.

\section{Materials and Methods}

\subsection{Study site}

The study site $\left(45^{\circ} 53^{\prime} 19.38^{\prime \prime} \mathrm{N} ; 7^{\circ} 51^{\prime} 03.26^{\prime \prime} \mathrm{E}\right)$ is located on the Indren glacier, which is a temperate glacier of about 100 ha in size, located in the Northwestern Alps in the Aosta Valley, Italy, and belongs to the Long-Term Ecological Research (LTER) Istituto Mosso site. Elevation ranges from 3000 to $4100 \mathrm{~m}$ ASL, with a predominantly southwest aspect. Most seasonal snow accumulation results from snowfall, but drifting snow and avalanches also contribute to the seasonal snowpack on the glacier (Maggioni et al. 2009). The foreland of the Indren glacier lies, at $3000-3100 \mathrm{~m}$ ASL which is above the actual treeline. The mean annual air temperature near the glacier terminus is $-4^{\circ} \mathrm{C}$, mean annual precipitation is $1500 \mathrm{~mm}$, and snow cover usually lasts from early-October to late June (Maggioni et al. 2009). The moraines are composed of micaschist and gneiss. The surface of the glacier in the ablation zone is heavily crevassed and supraglacial drainage is routed via several small streams that flow into a small proglacial lake, drained by a small alpine stream. During a survey of the Indren Glacier foreland in the middle of August 2003, some unusual mineral debris were discovered in the recently deglaciated area. These sediments were observed on a stony counter slope in an area that until autumn 2002 was occupied
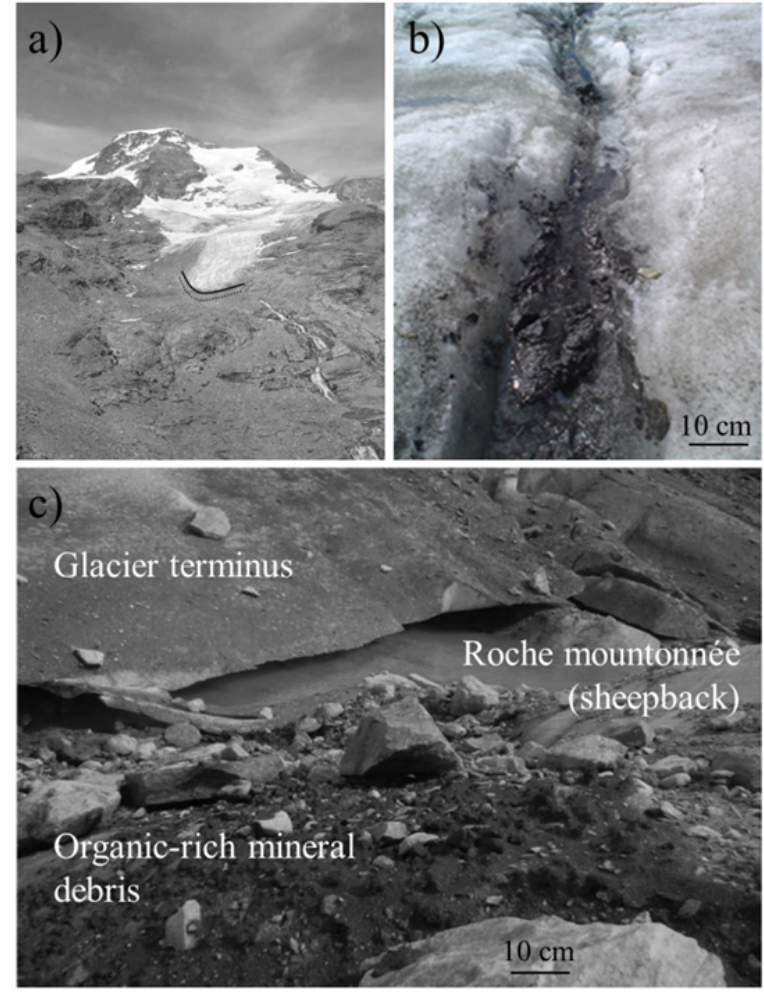

Fig. 1 a) Indren glacier during summer 2003. The black line and dotted line indicate the location of the glacier terminus in 2003 and 2002, respectively. b) Bedières running on the glacier surface in 2003. c) Organic-rich mineral debris in 2003, located 3 meters from the glacier terminus.

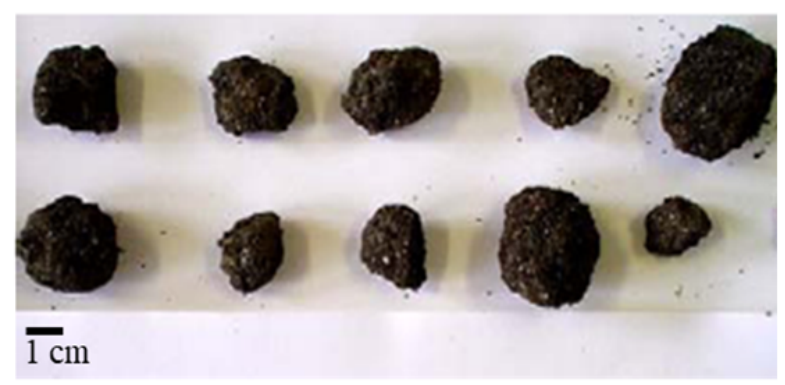

Fig. 2 Single aggregates found in the organic-rich mineral debris discovered at the Indren glacier foreland in August, 2003.

by the glacier, covering an area of about $10 \mathrm{~m}^{2}$ (Fig. 1). The size of the individual aggregates which constituted the mineral debris ranged from 1 to $3 \mathrm{~cm}$ (Fig. 2).

\subsection{Sampling procedure}

These sediments were initially sampled in August 2003 in six replicates, each one consisting of a layer of an area of $10 \mathrm{~cm}^{2}$ and a depth of $1-3 \mathrm{~cm}$. The samples 
were collected into sterile $100-\mathrm{mL}$ polypropylene bags using a sterile spatula. After collection, the samples were maintained at low temperature to limit biological activity during transport and analyzed immediately after being returned to the laboratory for microbial biomass, $\mathrm{N}$ and $\mathrm{P}$ forms determination. Aliquots of each sample were stored dried, for further chemical characterization, or frozen at $-20^{\circ} \mathrm{C}$ for molecular analyses. Further 6 samples were collected in August 2004 using the same field protocols and sampling location. Glacial meltwater was sampled in both years in the glacier outflow adjacent to the location of the sediments in order to evaluate its contribution to the formation of the organic-rich mineral deposits. Water from the glacial outflow was collected in 500-cc clean polyethylene bottles, filtered (pre-ashed Whatman GF/F filters; $0.7 \mu \mathrm{m}$ ) within 1 to $4 \mathrm{~h}$, and stored for 1 to $3 \mathrm{~d}$ at $4^{\circ} \mathrm{C}$ prior to analysis.

\subsection{General characterization of sediment and glacier outflow samples}

The color of the material was determined in the laboratory using Munsell charts. The structure was described in the undisturbed samples according to the Guidelines for the Soil Description (IUSS Working Group 2006). All samples of the sediments were air dried to constant weight, ground and sieved $(2 \mathrm{~mm})$ before conducting the chemical analyses. An aliquot of each fresh sample was dried at $105^{\circ} \mathrm{C}$ to determine moisture content. Electrical conductivity (EC) and $\mathrm{pH}$ were measured potentiometrically in water $(1: 2.5$ $\mathrm{w} / \mathrm{v}$ ). Total organic carbon (TOC) and total nitrogen (TN) were determined by total oxidation using a $\mathrm{CN}$ analyzer (CE Instruments, NA210o Protein, Milan, Italy). The cation exchange capacity (CEC) and the exchangeable cations were determined in a $\mathrm{BaCl}_{2}$ solution buffered at $\mathrm{pH} 8.1$ (Rhoades 1983).

For the water samples, $\mathrm{pH}$ and EC were determined potentiometrically and DOC content was measured using a TOC analyzer (TOC-Vario Elementar, Hannover, Germany). Fluorescence measurements were conducted on the DOC in the water samples using a Fluoromax-2 multi-wavelength fluorescence spectrophotometer with a xenon lamp. Samples were scanned in an optically clear quartz cuvette. Scans were performed at an excitation wavelength of $370 \mathrm{~nm}$, for emissions wavelengths between 370 and $700 \mathrm{~nm}$ at $1-\mathrm{nm}$ increments. Scans of sample blanks of deionized water were performed, and the blank fluorescence values were subtracted from the raw scans of the samples in order to remove the effects of Raman scattering (Lafrenière and Sharp 2004). After subtracting the blank, the Fluorescence Index (FI-the ratio of emission intensity at $450 \mathrm{~nm}$ to $500 \mathrm{~nm}$ for an excitation of $370 \mathrm{~nm}$ ) was determined (Mcknight et al. 2001).

\subsection{Nitrogen and phosphorus forms}

To better characterize the sediments and obtain more information on their genesis, further analyses were carried out on the samples collected in 2004. As a base for several analyses, $10 \mathrm{~g}$ of the fresh material were added to $50 \mathrm{~mL}$ of $0.5 \mathrm{M} \mathrm{K}_{2} \mathrm{SO}_{4}$, shaken for $1 \mathrm{~h}$, centrifuged and filtered $(0.45 \mu \mathrm{m})$, obtaining a solution that will be referred as $\mathrm{K}_{2} \mathrm{SO}_{4}$ extract.

Total dissolved nitrogen (TDN) was measured in $\mathrm{K}_{2} \mathrm{SO}_{4}$ extracts as $\mathrm{N}^{-\mathrm{NH}_{4}}{ }^{+}$after oxidation with potassium persulfate and subsequent reduction with Devarda alloy (Williams et al. 1995). Ammonium and nitrate concentrations were determined sequentially on the same aliquot of $\mathrm{K}_{2} \mathrm{SO}_{4}$ extract. Firstly, ammonium was diffused into $0.01 \mathrm{M} \mathrm{H}_{2} \mathrm{SO}_{4}$ after treatment of the extract with $\mathrm{MgO}$ (Bremner 1965), and the trapped $\mathrm{NH}_{4}{ }^{+}$was determined colorimetrically (Crooke and Simpson 1971). Then, $\mathrm{NO}_{3}{ }^{-}$concentration was determined colorimetrically as $\mathrm{NH}_{4}{ }^{+}$after the reduction of the remaining extract with Devarda alloy. Extractable DON was calculated as $\mathrm{DON}=\mathrm{TDN}-\left(\mathrm{N}-\mathrm{NH}_{4}{ }^{+}+\mathrm{N}^{-} \mathrm{NO}_{3}{ }^{-}\right)$.

Total phosphorus (TP) was determined after $\mathrm{H}_{2} \mathrm{SO}_{4}-\mathrm{HClO}_{4}$ digestion of the organo-mineral deposits (Kuo 1996) by measuring the amount of $\mathrm{P}$ in solution with malachite green as described by Ohno and Zibilske (1991). Also, dissolved inorganic phosphorus (DIP) and total dissolved phosphorus (TDP) were determined with the malachite green method, applied directly on $\mathrm{K}_{2} \mathrm{SO}_{4}$ extracts for DIP or after the oxidation of the extracts with potassium persulfate for TDP (Williams et al. 1995). Dissolved organic phosphorus (DOP) was calculated by difference between TDP and DIP.

\subsection{Microbial biomass}

To measure microbial biomass $\mathrm{C}$ and $\mathrm{N}$, a set of fresh samples was fumigated overnight with chloroform and extracted with $0.5 \mathrm{M} \mathrm{K}_{2} \mathrm{SO}_{4}$ as described above, in parallel with a set of non- 
fumigated samples (Williams and Sparling 1988). Biomass- $\mathrm{C}$ and $-\mathrm{N}$ values were calculated from the flushes of extractable $\mathrm{C}$ and $\mathrm{N}$ using the recovery factors of 0.45 for C (Sarathchandra et al. 1989) and 0.54 for $\mathrm{N}$ (Brookes et al. 1985). Microbial P was determined by the procedure used by Brookes et al. (1982), with a conversion factor equal to 0.40 .

\subsection{Organic matter fractionation and characterization}

To evaluate the origin and composition of the organic material in the deposits, the samples collected in 2004 were subjected to a combined chemical fractionation procedure used in soil and organic rich matrices (Cerli et al. 2008). All the reagents used were Sigma-Aldrich, ACS grade (unless otherwise specified). Although the chemical extraction cannot give information on organic matter fractions based on their turnover (Kögel-Knabner and Rumpel 2018), it can allow for a better elemental and chemical characterization, which is the aim of the present work.

The samples were firstly treated with deionized water (1:10 solid/water ratio) to separate the water extractable organic matter (WEOM) and then subjected to $0.1 \mathrm{M} \mathrm{NaOH}$ extraction (soil: liquid ratio 1:10) under $\mathrm{N}_{2}$ flux. The carbon content in the WEOM and alkaline extracted fractions (WEOC and AEOC, respectively) was determined on an aliquot of the obtained solutions using a TOC analyzer (TOC-Vario Elementar, Hannover, Germany). The nonextractable organic $\mathrm{C}$ (NE-C) was determined by difference between TOC and (WEOC+AEOC). The alkaline fraction was then treated with $6 \mathrm{M} \mathrm{HCl}$ to induce the precipitation of the less soluble fraction, the so called humic acids (HA). The supernatant containing highly soluble compounds, called fulvic acids (FA), was separated from the precipitate by centrifugation at $1516 \mathrm{x}$ g for $15 \mathrm{~min}$. Humic acids were demineralized by shaking overnight with a $0.1 \mathrm{M}$ $\mathrm{HCl}$ :0.3 M HF solution (solid: liquid ratio 1:1) and then washed with deionized water until the solution $\mathrm{pH}$ was 3. Fulvic acids were concentrated using XAD8 and IR-12O resins. Both HA and FA solutions were then freeze-dried. During FA concentration, a large part of the organic compounds was not retained in the XAD-8 fraction. This fraction was collected, freezedried and called non-retained fraction (NRF). WEOM, FA, NRF, and HA were characterized for their elemental (C, N, H, S) composition by a $\mathrm{CHN}-600$ combustion analyzer (LECO, St Joseph, Michigan, USA), while the $\mathrm{O}$ content was calculated by difference. The obtained data were corrected for ash and moisture content. The presence of polar groups and aromatic/aliphatic component were assessed by determining the ratio between the optical density measured at 450 and $650 \mathrm{~nm}\left(\mathrm{E}_{4} / \mathrm{E}_{6}\right.$ ratio $)$ on samples dissolved in $50 \mathrm{~mL}$ of $0.05 \mathrm{~N} \mathrm{NaHCO}_{3}$ (Chen et al. 1977). Fourier-Transform infrared spectra on the different organic fractions were obtained using a Perkin Elmer 16F PC FT-IR spectrophotometer. The pellets were prepared by pressing under vacuum a mixture of $1 \mathrm{mg}$ of organic material with $400 \mathrm{mg}$ of $\mathrm{KBr}$ (spectrometry grade). Spectra were acquired at 4 $\mathrm{cm}^{-1}$ resolution and 64 scans were averaged. The interpretation of the FT-IR spectra is based on procedures reported in Celi et al. (1997) and references therein.

\subsection{Radiocarbon dating of the organic-rich mineral deposits}

One of the samples collected in 2004 was cleaned using an acid-alkali-acid treatment. The sample was heated at $900^{\circ} \mathrm{C}$ to obtain $\mathrm{CO}_{2}$. The $\mathrm{CO}_{2}$ of the combusted sample was mixed with $\mathrm{H}_{2}$ (1:2.5) and catalytically reduced over iron powder at $535^{\circ} \mathrm{C}$ to elemental carbon (graphite). After reduction, the mixture was pressed into a target and carbon ratio was measured by Accelerator Mass Spectrometry (AMS) using 0.2 MV radiocarbon dating facility (MICADAS) of the Ion Beam Physics at the Swiss Federal Institute of Technology Zurich.

The calendar age was obtained using the OxCal 4.2 calibration program (Bronk Ramsey 2001, 2009) based on the IntCal 13 calibration curve (Reimer et al. 2013). The calibrated age is given in the 1 sigma and 2 sigma range (minimum and maximum value for each).

\subsection{Elemental composition and trace elements}

For elemental composition and trace element determination, $500 \mathrm{mg}$ of the $<2 \mathrm{~mm}$ samples (2004) were ground and then weighed into a Teflon polytetrafluoroacetate (PFA) digestion vessel, to which $6 \mathrm{~mL}$ of $\mathrm{HCl}, 2 \mathrm{~mL}$ of $\mathrm{HNO}_{3}$ and $3 \mathrm{~mL}$ of $\mathrm{H}_{2} \mathrm{O}_{2}$ were slowly added. Digestion was performed using a microwave system (MARS 5; CEM, Matthews, NC, USA) using a controlled dynamic program (6oo $\mathrm{W}$ for $15 \mathrm{~min}$ at $120^{\circ} \mathrm{C}, 900 \mathrm{~W}$ for $20 \mathrm{~min}$ at $180^{\circ} \mathrm{C}$ ). 
Following digestion, samples were cooled to ambient temperature, separated from the insoluble residue by filtration through pre-cleaned $0.45-\mu \mathrm{m}$ membrane filters and the remaining insoluble residue, as well as the vessel, were rinsed with ultra-pure water (Purelab Ultra-Analytic, ElgaLabWater, High Wycombe, UK). Concentrations of 41 elements including 14 rare earth elements (REE) were determined by a quadrupole Inductively Coupled Plasma Mass Spectrometry (ICPMS) (Agilent 7500; Agilent Technologies, Tokyo, Japan) equipped with an inlet system consisting of a PFA nebulizer (Elemental Scientific) and a water cooled $\left(4^{\circ} \mathrm{C}\right)$ Scott-type spray chamber. An external calibration curve method was used for the quantification of analytes. Standard solutions were prepared by diluting trace elements (ICUS-2012, 10 ppm; ULTRA Scientific, N. Kingstown, RD, USA) and REE (IMS-101, 10 ppm; ULTRA Scientific, N. Kingstown, RD, USA) multi-standard stock solution. Calibrations were performed using 5 standards with concentrations ranging between 0.10 to $1000 \mu \mathrm{kg}^{-1}$, using Yttrium as an internal standard. Ultra-pure water was used in all the dilutions. The recoveries obtained analyzing a certificate reference material (CRM BCR-141R; IRMM, Geel, Belgium) ranged from $81 \%(\mathrm{Ti})$ to $98 \%(\mathrm{~Pb})$ with a precision ranging from $5.7 \%(\mathrm{Tl})$ to $18.8 \%(\mathrm{Cd})$. The degree to which elements are introduced from rock and soil dust was assessed by calculating crustal enrichment factors $\mathrm{EF}_{(\mathrm{Ba})}$ following the protocol of Lawrence et al. (2010). $\mathrm{EF}(\mathrm{Ba})$ is defined as the concentration ratio of a given element to that of $\mathrm{Ba}$ (which is a good approximation of rock and soil dust), normalized to the same concentration ratio characteristic of the upper continental crust. Here, we have used the data for the upper continental crust given by Wedepohl (1995). The primary uncertainty in these calculations is attributed to the differences between chemical composition of local soil and reference crustal composition. $\mathrm{EF}_{(\mathrm{Ba})}$ values should therefore be qualitatively used in evaluating the relative contribution from rock and soil dust.

\subsection{Microbial abundance and diversity}

DNA was extracted from $500 \mathrm{mg}$ of the samples collected in 2004 using the FastDNA ${ }^{\circledR}$ Spin Kit for soil (MP Biomedicals, Santa Ana, CA, USA). The obtained DNA pellet was re-suspended in $50 \mu \mathrm{L}$ of sterile, DNase free water (Sigma-Aldrich) and the quantity and quality of extracted DNA was evaluated using a NanoDrop ND-100o spectrophotometer (Nanodrop Technologies, Wilmington, DE, USA). Five microliters of extracted DNA were separated by agarose gel (1\%) electrophoresis at $100 \mathrm{~V}$ for $60 \mathrm{~min}$ in TAE buffer $1 \mathrm{X}$ and visualized under UV light after staining with ethidium bromide, to assess the quality of extracted DNA in terms of molecular weight and fragment length distribution.

The abundance of Archaea and Bacteria was assessed by quantitative Polymerase Chain Reaction (qPCR) on 16S rRNA genes as described in Mania et al. (2016). Archaeal and bacterial community structure were investigated, based on the same marker genes, by Denaturing Gradient Gel Electrophoresis (DGGE), and dominant Archaea bands were excised and sequenced, as previously described (Mania et al. 2016).

Due to the higher complexity of bacterial profiles, no DGGE bands were sequenced for Bacteria, but DNA replicates from 2004 were pooled together and analyzed by Tag-encoded FLX amplicon pyrosequencing using a Roche 454 FLX instrument at RTL Genomics (Lubbock, TX, USA). Sample preparation and bioinformatic analysis of sequencing data have been performed as previously described (Cocolin et al. 2013).

\subsection{Statistical analysis}

The differences in chemical properties between the sampling years were tested with one-way ANOVA or, when the ANOVA assumptions were violated, with Kruskal-Wallis rank sum test. Correlations between the different parameters were carried out using the Pearson correlation coefficient. All the statistical analyses were carried out using SPSS 12.0 for Windows.

\section{Results}

\subsection{General characteristics of the organic-rich mineral deposits and meltwater samples}

The general characteristics of the organic-rich mineral deposits and the meltwater samples are summarized in Table 1 and Table 2. Briefly, the color of the dry samples was black $(2.5 \mathrm{Y} 2.5 / 1)$, and the structure was always granular, moderate in 2003, 
Table 1 Main characteristics of the organic-rich mineral deposits sampled in $2003(n=6)$ and 2004 $(n=6)$. TOC: total organic carbon; EC: electrical conductivity; CEC: cation exchange capacity; $\mathrm{Ca}_{\mathrm{ex}}, \mathrm{Mg}_{\mathrm{ex}}$, $\mathrm{K}_{\mathrm{ex}}, \mathrm{Na}_{\mathrm{ex}}$ : exchangeable cations; BS: base saturation. Values reported in brackets are standard deviations, and different letters indicate significant differences $(p<0.05)$ between years.

\begin{tabular}{|c|c|c|c|}
\hline \multicolumn{2}{|c|}{ Characteristics } & 2003 & 2004 \\
\hline \multicolumn{2}{|l|}{ Color dry } & $2.5 \mathrm{Y} 2.5 / 1$ & $2.5 \mathrm{Y} 2.5 / 1$ \\
\hline \multirow{3}{*}{ Structure } & grade & moderate & weak \\
\hline & form & granular & granular \\
\hline & size & very coarse & coarse \\
\hline \multicolumn{2}{|c|}{ TOC $\left(\mathrm{g} \mathrm{kg}^{-1}\right)$} & $28.1(0.63) \mathrm{a}$ & $17.4(0.39) \mathrm{b}$ \\
\hline \multicolumn{2}{|l|}{$\mathrm{TOC} / \mathrm{TN}$} & $9.79(0.13)$ & $12.2(1.88)$ \\
\hline \multicolumn{2}{|l|}{$\mathrm{pH} \mathrm{H} \mathrm{H}_{2} \mathrm{O}$} & $6.32(0.22) \mathrm{a}$ & $5.62(0.18) \mathrm{b}$ \\
\hline \multicolumn{2}{|c|}{$\mathrm{EC}\left(\mu \mathrm{S} \mathrm{cm}^{-1}\right)$} & $179(21.2) \mathrm{a}$ & $78.9(21.5) \mathrm{b}$ \\
\hline \multicolumn{2}{|c|}{$\mathrm{CEC}\left(\mathrm{cmol}_{(+)} \mathrm{kg}^{-1}\right)$} & $12.1(0.45) \mathrm{a}$ & $6.53(2.24) \mathrm{b}$ \\
\hline \multicolumn{2}{|c|}{$\mathrm{Ca}_{\mathrm{ex}}\left(\mathrm{cmol}_{(+)} \mathrm{kg}^{-1}\right)$} & $1.67(0.61)$ & $1.53(0.69)$ \\
\hline \multicolumn{2}{|c|}{$\operatorname{Mg}_{\text {ex }}\left(\mathrm{cmol}_{(+)} \mathrm{kg}^{-1}\right)$} & $0.73(0.07) \mathrm{a}$ & $0.33(0.08) \mathrm{b}$ \\
\hline \multicolumn{2}{|c|}{$\mathrm{K}_{\mathrm{ex}}\left(\mathrm{cmol}_{(+)} \mathrm{kg}^{-1}\right)$} & $0.29(0.01) \mathrm{a}$ & $0.16(0.05) \mathrm{b}$ \\
\hline \multicolumn{2}{|c|}{$\mathrm{Naex}\left(\mathrm{cmol}_{(+)} \mathrm{kg}^{-1}\right)$} & $0.11(0.02)$ & $0.13(0.03)$ \\
\hline \multicolumn{2}{|l|}{ BS (\%) } & $23.3(5.51)$ & $33.6(5.94)$ \\
\hline
\end{tabular}

weak in 2004. The base saturation was lower than 50\% in all samples. For the base cations, calcium showed the greatest concentration, sodium the lowest. The electrical conductivity (EC), cation exchange capacity (CEC), pH and total organic carbon (TOC) significantly decreased from 2003 to 2004. In contrast, the TOC/TN ratio showed an opposite trend with greater values in 2004. A significant positive correlation ( $r=0.96 ; p<0.01$ ) was found between TOC and CEC, as with the exchangeable cations $\mathrm{Mg}$ $(r=0.95 ; p<0.01)$ and $\mathrm{K}(r=0.96 ; p<0.01)$.
The $\mathrm{pH}$ and temperature of glacial meltwater showed no significant differences between sampling times. The EC and Fluorescence Index were characterized by significantly higher values during 2004, while the DOC concentration was significantly lower in 2004 than in 2003.

\subsection{Carbon, nitrogen and phosphorus forms}

The distribution of $\mathrm{C}$ and $\mathrm{N}$ in the different forms highlighted that up to $10.6 \%$ of $\mathrm{C}$ and $3.13 \%$ of $\mathrm{N}$ was composed of microbial material, which contained a low amount of $\mathrm{P}$ (Table 3). The largest amount of $\mathrm{C}$ was found in the alkaline extract (AEOC), representing more than $50 \%$ of TOC. The water extractable organic fraction included instead a smaller portion of TOC. The greatest amount of dissolved $\mathrm{N}$ was found in inorganic forms, mainly as ammonium. However, total dissolved $\mathrm{N}$ (comprising both organic and inorganic forms), represented only $2.40 \%$ of $\mathrm{TN}$, indicating that more than $97 \%$ of $\mathrm{TN}$ was present as particulate $\mathrm{N}$. Total $\mathrm{P}$ showed that the sediments contained a considerable amount of P-minerals, with less than $0.5 \%$ of TP in dissolved and microbial forms.

\subsection{Organic matter characteristics}

The water extractable organic material (WEOM) was characterized by high $\mathrm{N}, \mathrm{S}$ and $\mathrm{O}$ contents, which led to low $\mathrm{C} / \mathrm{N}$ and quite high $\mathrm{O} / \mathrm{C}$ ratios (Table 4 ). Fig. 3 shows the FT-IR spectra with the main band

Table 2 Main characteristics of the glacier meltwater samples collected from the outflow of the Indren glacier during summer 2003 and $2004(n=12)$. EC: electrical conductivity; DOC: dissolved organic carbon; FI: Fluorescence Index. Values reported in brackets are standard deviations, and different letters indicate significant differences $(p<0.05)$ between years.

\begin{tabular}{|l|l|l|l|l|l|}
\hline Year & $T\left({ }^{\circ} \mathrm{C}\right)$ & $\mathrm{pH}$ & $\mathrm{EC}\left(\mu \mathrm{S} \mathrm{cm}{ }^{-1}\right)$ & DOC $\left(\mathrm{mg} \mathrm{L}^{-1}\right)$ \\
\hline 2003 & $3.28(0.16)$ & $6.53(0.06)$ & $108(24.96) \mathrm{b}$ & $3.16(0.26) \mathrm{a}$ & $1.75( \pm 0.01) \mathrm{b}$ \\
\hline 2004 & $3.19(0.05)$ & $6.50(0.03)$ & $150(2.51) \mathrm{a}$ & $1.89(0.05) \mathrm{b}$ & $1.93( \pm 0.14) \mathrm{a}$ \\
\hline
\end{tabular}

Table 3 Main C, N, P forms in the organic-rich mineral deposit sampled in August 2004 ( $n=6)$.

\begin{tabular}{|c|c|c|c|c|c|c|c|c|}
\hline $\begin{array}{l}\text { Carbon } \\
\text { forms }\end{array}$ & $\mathrm{mg} \mathrm{C} \mathrm{kg}^{-1}$ & $\%$ TOC & $\begin{array}{l}\text { Nitrogen } \\
\text { forms }\end{array}$ & $\mathrm{mg} \mathrm{N} \mathrm{kg}^{-1}$ & $\% \mathrm{TN}$ & $\begin{array}{l}\text { Phosphorus } \\
\text { forms }\end{array}$ & $\mathrm{mg} \mathrm{P} \mathrm{kg}^{-1}$ & $\% \mathrm{TP}$ \\
\hline TOC & 17400 & & TN & 1510 & & TP & 1012 & \\
\hline $\mathrm{C}_{\text {micr }}$ & 1850 & 10.6 & $\mathrm{~N}_{\text {micr }}$ & $47 \cdot 3$ & 3.13 & $P_{\text {micr }}$ & 1.37 & 0.14 \\
\hline WEOC & 57.4 & 0.33 & DON & 2.53 & 0.17 & DOP & 0.23 & 0.02 \\
\hline AEOC & 9700 & $55 \cdot 7$ & $\mathrm{NH}_{4}{ }^{+}$ & 31.0 & 2.05 & DIP & 0.29 & 0.03 \\
\hline $\mathrm{C}_{\mathrm{FA}+\mathrm{NRF}}$ & 6400 & 36.8 & $\mathrm{NO}_{3}^{-}$ & 2.73 & 0.18 & & & \\
\hline $\mathrm{C}_{\mathrm{HA}}$ & 3300 & 19.0 & $\mathrm{C}_{\text {micr }} / \mathrm{N}_{\text {micr }}$ & 39 & & & & \\
\hline
\end{tabular}

Notes: \%TOC, \%TN and \%TP: percentage of C, N, P forms as proportion of TOC, TN and TP. TOC: total organic C; $\mathrm{C}_{\text {micr: }}$ : microbial C; WEOC: water extractable organic C; AEOC: alkaline extractable organic C; $\mathrm{C}_{\mathrm{FA}+\mathrm{NRF}}$ : $\mathrm{C}$ content in the fulvic acids and not retained fulvic fractions; $\mathrm{C}_{\mathrm{HA}}$ : $\mathrm{C}$ content in the humic acids; TN: total nitrogen; $\mathrm{N}_{\text {micr: }}$ microbial N; DON: dissolved organic $\mathrm{N} ; \mathrm{NH}_{4}{ }^{+}$: ammonium; $\mathrm{NO}_{3}^{-}$: nitrate; TP: total phosphorus; $\mathrm{P}_{\text {micr: }}$ microbial P; DOP: dissolved organic phosphorus; DIP: dissolved inorganic phosphorus 
Table 4 Elemental composition (\%), elemental ratios and $\mathrm{E}_{4} / \mathrm{E}_{6}$ ratio of the organic fractions extracted from organicrich mineral debris sampled in 2004. WEOM: water extractable organic matter; NRF: non-retained acidic fraction; FA: fulvic acids; HA: humic acids. Values reported in brackets are standard deviations.

\begin{tabular}{|c|c|c|c|c|c|c|c|c|c|c|}
\hline Parameters & $\mathrm{C}$ & $\mathrm{N}$ & $\mathrm{H}$ & S & $\mathrm{O}$ & $\mathrm{H} / \mathrm{C}$ & $\mathrm{C} / \mathrm{N}$ & $\mathrm{O} / \mathrm{C}$ & $\mathrm{S} / \mathrm{N}$ & $\mathrm{E}_{4} / \mathrm{E}_{6}$ \\
\hline WEOM & $\begin{array}{l}38.33 \\
(1.98)\end{array}$ & $\begin{array}{l}7.89 \\
(1.04)\end{array}$ & $\begin{array}{l}6.12 \\
(0.18)\end{array}$ & $\begin{array}{l}4.81 \\
(1.90)\end{array}$ & $\begin{array}{l}43.51 \\
(1.48)\end{array}$ & $\begin{array}{l}1.92 \\
(0.08)\end{array}$ & $\begin{array}{l}5.72 \\
(0.84)\end{array}$ & $\begin{array}{l}0.84 \\
(0.04)\end{array}$ & $\begin{array}{l}0.27 \\
(0.06)\end{array}$ & $\begin{array}{l}2.05 \\
(0.21)\end{array}$ \\
\hline NRF & $\begin{array}{l}42.56 \\
(2.38)\end{array}$ & $\begin{array}{l}1.96 \\
(0.37)\end{array}$ & $\begin{array}{l}5.05 \\
(0.82)\end{array}$ & $\begin{array}{l}7.8 \\
(0.92)\end{array}$ & $\begin{array}{l}42.56 \\
(3.28)\end{array}$ & $\begin{array}{l}1.42 \\
(0.16)\end{array}$ & $\begin{array}{l}26.03 \\
(4.80)\end{array}$ & $\begin{array}{l}0.76 \\
(0.10)\end{array}$ & $\begin{array}{l}1.83 \\
(0.53)\end{array}$ & $\begin{array}{l}4.23 \\
(1.20)\end{array}$ \\
\hline FA & $\begin{array}{l}51.02 \\
(2.20)\end{array}$ & $\begin{array}{l}7.00 \\
(2.91)\end{array}$ & $\begin{array}{l}6.16 \\
(0.76)\end{array}$ & $\begin{array}{l}2.73 \\
(0.76)\end{array}$ & $\begin{array}{l}33.09 \\
(3.38)\end{array}$ & $\begin{array}{l}1.45 \\
(0.21)\end{array}$ & $\begin{array}{l}9.75 \\
(4.06)\end{array}$ & $\begin{array}{l}0.49 \\
(0.07)\end{array}$ & $\begin{array}{l}0.21 \\
(0.13)\end{array}$ & $\begin{array}{l}9.82 \\
(0.80)\end{array}$ \\
\hline HA & $\begin{array}{l}63.03 \\
(3.01)\end{array}$ & $\begin{array}{l}5.80 \\
(0.17)\end{array}$ & $\begin{array}{l}6.68 \\
(0.31)\end{array}$ & $\begin{array}{l}1.83 \\
\text { (o.01) }\end{array}$ & $\begin{array}{l}22.81 \\
(2.63)\end{array}$ & $\begin{array}{l}1.28 \\
(0.10)\end{array}$ & $\begin{array}{l}12.70 \\
(0.97)\end{array}$ & $\begin{array}{l}0.27 \\
(0.04)\end{array}$ & $\begin{array}{l}0.14 \\
\text { (o.0o) }\end{array}$ & $\begin{array}{l}1.63 \\
(0.06)\end{array}$ \\
\hline
\end{tabular}

Table 5 Main FT-IR spectra band assignments and corresponding types of groups or compounds.

\begin{tabular}{|l|l|l|}
\hline Frequency $\left(\mathrm{cm}^{-1}\right)$ & Band assignment & Functional groups or compounds \\
\hline 2934 & $-\mathrm{CH}_{3}$ stretching & Aliphatic \\
\hline 2849 & $-\mathrm{CH}$ - stretching & Aliphatic \\
\hline $1732-1708$ & $-\mathrm{C}-\mathrm{O}$ stretching & $-\mathrm{C}=\mathrm{O}$ and $-\mathrm{COOH}$ \\
\hline $1660-1650$ & $-\mathrm{C}=\mathrm{C}$ - stretching & Aromatic \\
\hline 1655 & $-\mathrm{NH}_{3}{ }^{+}$stretching & Free amino acids \\
\hline $1535-1520$ & $-\mathrm{CONH}^{-}$of amide II & Peptides or proteins \\
\hline $1400-1384$ & $-\mathrm{CH}_{2}-$ and $-\mathrm{CH}_{3}$ bending & Aliphatic \\
\hline $1233-1231$ & $-\mathrm{C}-\mathrm{O}$ asymm. stretching and $-\mathrm{OH}$ bending & Saccharides \\
\hline $1160-1150$ & $\mathrm{C}-\mathrm{O}$ and OH bending & Saccharides \\
\hline $1080-969$ & $\mathrm{C}-\mathrm{OH}$ stretching & Alcoholic or phenolic \\
\hline
\end{tabular}

frequencies; their assignments are reported in Table 5 . In the WEOM spectrum the shoulders at $2934 \mathrm{~cm}^{-1}$, $1724 \mathrm{~cm}^{-1}$ and the band at $1244 \mathrm{~cm}^{-1}$, together with the sharper band at $1655 \mathrm{~cm}^{-1}$, may suggest that the high content of $\mathrm{N}$ and $\mathrm{S}$ was related to the presence of simple amino acids. However, the band at $1542 \mathrm{~cm}^{-1}$, generally attributed to secondary amides, indicated also the presence of soluble oligopeptides (Sodano et al. 2016). However, more pronounced bands occurred at $1400 \mathrm{~cm}^{-1}$ and $1384 \mathrm{~cm}^{-1}$ and in the $1100-1000 \mathrm{~cm}^{-1}$ region, suggesting that oxygen-derived groups mostly belonged to mono- and oligosaccharides. The low $\mathrm{E}_{4} / \mathrm{E}_{6}$ (Table 4) may be related to the presence of fresh or unaltered material poor in carboxyl and phenolic functional groups (Chen et al. 1977).

The organic material was characterized by a large proportion of $\mathrm{NaOH}$ extractable compounds, mainly represented by non-humified material, i.e., NRF (Table 3). In contrast to the water extractable fraction, the latter was characterized by low $\mathrm{N}$ values and high $\mathrm{O} / \mathrm{C}$ and $\mathrm{H} / \mathrm{C}$ ratios (Table 4, Fig. 3), highlighting the dominance of high polar aliphatic compounds (Andreux and Piccolo 1996). The FT-IR spectrum of this fraction showed a pronounced band in the 1200$1000 \mathrm{~cm}^{-1}$ region, due to $\mathrm{C}-\mathrm{O}$ bending, indicating the prevalence of almost unaltered saccharide residues.

Fulvic acids were composed by unusually high contents of $\mathrm{H}, \mathrm{N}$ and $\mathrm{S}$ compared to soil derived FA (i.e., Agnelli et al. 2002). The resulting $\mathrm{H} / \mathrm{C}$ ratio

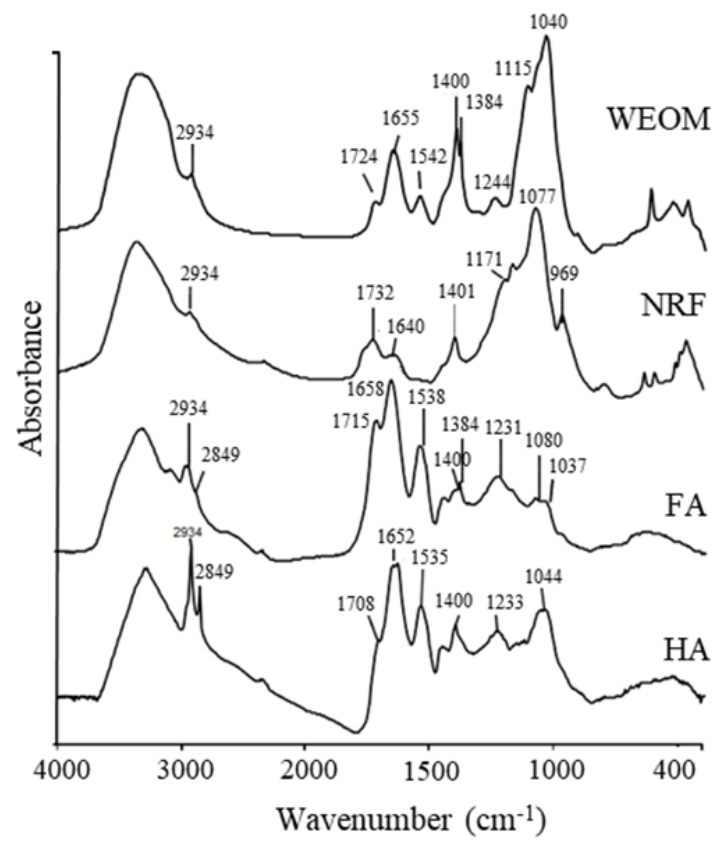

Fig. 3 FT-IR spectra of water extractable organic matter (WEOM), non-retained fraction (NRF), fulvic acids (FA) and humic acids (HA) extracted from the organic-rich samples collected in 2004.

suggested that the material was dominated by the aliphatic fraction. This was particularly evident in the FT-IR spectrum (Fig. 3) that showed well distinct peaks at 2963, 2937 and $2878 \mathrm{~cm}^{-1}$ due to aliphatic $\mathrm{CH}_{3}$ and $-\mathrm{CH}_{2}-\mathrm{C}-\mathrm{H}$ stretching, respectively. The low $\mathrm{C} / \mathrm{N}$ ratio suggested that these compounds were very 
rich in N-containing compounds and the pronounced band at $1538 \mathrm{~cm}^{-1}$ is consistent with the predominance of proteinaceous material. Conversely, the weaker bands at 1231, 1080 and $1037 \mathrm{~cm}^{-1}$, which are generally due to $\mathrm{C}-\mathrm{O}$ bending, highlighted a minor presence of saccharide residues. The oxygen present in this fraction may be then related to $-\mathrm{COOH}$ groups derived from a higher degree of decomposition compared to WEOM and NRF. This was deduced by the sharp peak present in the FT-IR spectrum at 1715 $\mathrm{cm}^{-1}$ and by the higher $\mathrm{E}_{4} / \mathrm{E}_{6}$ ratio with respect to the other fractions.

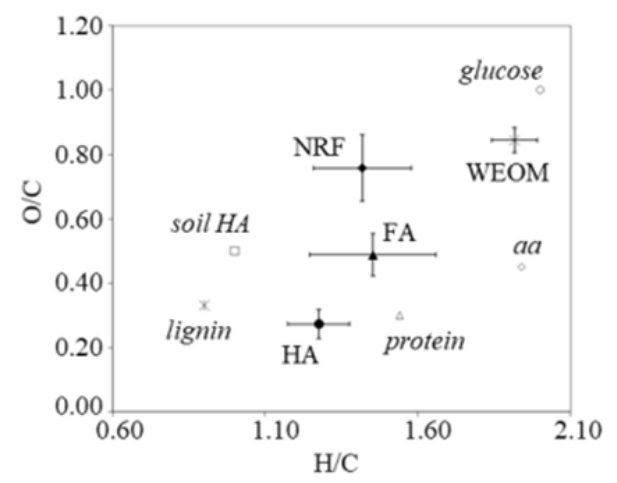

Fig. 4 Van Krevelen diagram of elemental composition $(\mathrm{O} / \mathrm{C}$ vs $\mathrm{H} / \mathrm{C})$ for water extractable organic matter (WEOM), non-retained fraction (NRF), fulvic acids (FA) and humic acids (HA) extracted from the organicrich mineral debris collected in 2004. For comparison, we plotted the relationship between $\mathrm{O} / \mathrm{C}$ and $\mathrm{H} / \mathrm{C}$ of lignin, glucose, a generic protein, amino acids (aa), and a typical soil HA (obtained by Celi et al. 1997).

By comparison, humic acids appeared richer in $\mathrm{C}$ and $\mathrm{N}$, with lower $\mathrm{H} / \mathrm{C}$, indicating a lower presence of aliphatic moieties. The reduction of aliphatic moieties in the humic acids was supported by the more pronounced band at 1652 and $1631 \mathrm{~cm}^{-1}$, most likely due to aromatic $\mathrm{C}=\mathrm{C}$ bonds. However, two pronounced peaks at 2919 and $2858 \mathrm{~cm}^{-1}$ due to aliphatic moieties were present in the HA spectrum. The $\mathrm{O} / \mathrm{C}$ was low, as confirmed by the weak shoulder at $1708 \mathrm{~cm}^{-1}$, due to $\mathrm{COOH}$ groups. For HA a pronounced band at $1535 \mathrm{~cm}^{-1}$ was present as well as the bands at 1233 and $1044 \mathrm{~cm}^{-1}$, suggesting the presence of unaltered proteinaceous and saccharidic remains.

The origin and the processes influencing the formation of organic material in the sediments were evaluated using the van Krevelen diagram (Fig. 4), which enables to characterize the organic matter in a "snapshot" and determine what types of molecules likely compose the sample (Kim et al. 2003). When $\mathrm{H} / \mathrm{C}$ versus $\mathrm{O} / \mathrm{C}$ (of each distinct empirical formula) is plotted for samples, distinct regions corresponding to different types of molecules emerge (Grannas et al. 2006). For our samples, the $\mathrm{O} / \mathrm{C}$ ratios ranged from 0.25 to 0.84 , the $\mathrm{H} / \mathrm{C}$ ratios ranged from 0.35 to 2.05 . The $\mathrm{O} / \mathrm{C}$ ratio increased in the order $\mathrm{HA}<\mathrm{FA}<\mathrm{WEOM}<\mathrm{NRF}$. In parallel WEOM and NRF elemental composition approached that of glucose and a generic amino acid. In contrast, FA and HA plotted closer to that of plant derived biocompounds, such as lignin, or typical soil HA (Celi et al. 1997), but without plotting in the general region of those compounds.

The overall age of the dated deposits was old with its age of about 2900 years (Table 6).

\subsection{Elemental composition and trace elements}

Using the aqua-regia dissolution, we determined the elemental composition of small particles, carbonates and organic material while the silicabound elements were not dissolved, keeping intact the geological matrix, which was principally composed of mica-schist and gneiss. In this way we determined the element concentrations in the fraction which could be influenced by non-autochthonous inputs such as atmospheric dust and biogenic materials (Gabrieli 2008). Summary statistics of elements and rare earth elements (REE) concentrations are reported in Table 7. Median concentrations of $\mathrm{P}$ and $\mathrm{Mn}$ were higher than $1000 \mathrm{mg} \mathrm{kg}^{-1}$, while $\mathrm{Pb}, \mathrm{Rb}, \mathrm{Zn}, \mathrm{Cr}$ and $\mathrm{Ba}$ median concentrations ranged between $120(\mathrm{Rb})$ to $513 \mathrm{mg} \mathrm{kg}^{-1}(\mathrm{Cr})$. Median concentrations of all other elements were lower, ranging from 1 to $100 \mathrm{mg} \mathrm{kg}^{-1}$ while the less abundant were $\mathrm{Cd}\left(0.20 \mathrm{mg} \mathrm{kg}^{-1}\right)$ and $\mathrm{Tl}$ $\left(0.46 \mathrm{mg} \mathrm{kg}^{-1}\right)$. REE concentrations ranged from 0.24 (Lu) to $92(\mathrm{Ce}) \mathrm{mg} \mathrm{kg}^{-1}$ (Table 7 ).

The enrichment or depletion of elements in dust relative to the Upper Continental Crust (UCC) provides some evidence for the origin of dust particles (Schütz and Rahn 1982; Schütz and Sebert 1987). Schütz and Rahn (1982) showed that because the

Table 6 Radiocarbon data of the organic-rich mineral deposits

\begin{tabular}{|c|c|c|c|c|c|}
\hline \multirow{2}{*}{ ETH no } & \multirow{2}{*}{ UZ no } & \multirow{2}{*}{ C-14 age (year) } & \multirow{2}{*}{${ }^{13} \mathrm{C}(\%)$} & \multicolumn{2}{|l|}{ Calibration } \\
\hline & & & & 1 sigma $(68.2 \%)$ & 2 sigma (95.4\%) \\
\hline 60748 & 6265 & $2785 \pm 30$ & $-39.5 \pm 1.0$ & $2849-2929$ cal BP & $2794-2956$ cal BP \\
\hline
\end{tabular}


geochemical composition of aerosol sized particles from desert soils are, in general, quite similar in element concentration to the UCC, the enrichment or depletion of dust relative to the UCC is a good point for comparison when the specific source soil is unknown (Lawrence et al. 2010). The enrichment factor $\left(\mathrm{EF}_{(\mathrm{Ba})}\right)$ calculated by normalization with UCC ranged between 1.0 (Co) and $178(\mathrm{Ag})$ (Table 8).

\subsection{Microbial abundance and diversity}

Total DNA amount of the sediment was on average $17.9 \pm 6.6(n=3) \mu \mathrm{g} \mathrm{g}^{-1}$ of dry weight. Gel electrophoresis indicated that the extracted DNA was of high quality (molecular weight) and low fragmentation (Appendix 1). The size of DNA extracted from the three replicates, notwithstanding differences in DNA yields, was about $10 \mathrm{~kb}$ with low smear on the gel and therefore with a very low fragmentation.

Archaeal and bacterial 16S rRNA genes, as quantified by qPCR, were in the range of 4.9 to 5.6 and 7.5 to 7.7 Log copies per gram of dry weight, respectively (data not shown).

Archaea DGGE profiles (Appendix 2) included a total of 4-5 bands, with only slight variations in terms of dominant bands among the samples. All the recovered bands referred to phylotypes affiliated to the orders Methanomicrobiales and Methanosarcinales.

Bacterial DGGE profiles (Appendix 2) showed a uniform community structure among all the samples, and the complex band pattern suggested the presence of a relatively diverse community. In terms of community composition, pyrosequencing data indicated that $70 \%$ of bacterial OTUs were affiliated to Actinobacteria (predominantly Actinomycetales), 10\% to Firmicutes (Clostridiales), 5\% to Gammaproteobacteria (Xanthomonadales), 4\% to Bacteroidetes (Flavobacteriales, Sphingobacteriales), $2 \%$ to Betaproteobacteria and Saccharibacteria and $1 \%$ to Alphaproteobacteria and Gemmatimonadetes (Fig. 5).

\section{Discussion}

The organic-rich mineral sediments found in the proglacial area of the Indren glacier in 2003 and 2004 were characterized by a coarse agglomeration of organic and mineral material, with apparently
Table 7 Elemental composition of organic-rich mineral samples collected in $2004(n=6) . \mathrm{EF}$ (Ba) represents the crustal enrichment factors.

\begin{tabular}{|c|c|c|c|c|}
\hline \multirow{2}{*}{ Element } & \multicolumn{3}{|c|}{ Concentrations (mg kg-1) } & \multirow{2}{*}{$\mathrm{EF}_{(\mathrm{Ba})}$} \\
\hline & Min & Max & Median & \\
\hline $\mathrm{Ag}$ & 3.8 & 7.4 & $5 \cdot 7$ & 178 \\
\hline As & 15 & 25 & 21 & 25 \\
\hline $\mathrm{Ba}$ & 242 & 347 & 288 & 1.0 \\
\hline $\mathrm{Be}$ & 1.1 & 1.5 & 1.2 & 1.1 \\
\hline $\mathrm{Bi}$ & 1.2 & 2.2 & 1.7 & 44 \\
\hline $\mathrm{Cd}$ & 0.15 & 0.23 & 0.20 & 3.9 \\
\hline $\mathrm{Ce}$ & 71 & 95 & 92 & 2.6 \\
\hline $\mathrm{Co}$ & 9.9 & 14.6 & 11.9 & 1.0 \\
\hline $\mathrm{Cr}$ & 411 & 575 & 513 & 7.7 \\
\hline $\mathrm{Cu}$ & 34 & 51 & 45 & 3.4 \\
\hline Dy & $3 \cdot 3$ & 4.4 & 4.2 & 2.1 \\
\hline $\mathrm{Er}$ & 1.7 & 2.4 & 2.1 & 1.8 \\
\hline $\mathrm{Eu}$ & 1 & 1.3 & 1.3 & 2.3 \\
\hline $\mathrm{Ga}$ & 27 & 36 & 29 & 4.0 \\
\hline Gd & 4.6 & 6.0 & 6.0 & 1.7 \\
\hline Ho & 0.62 & 0.86 & 0.79 & 1.9 \\
\hline $\mathrm{La}$ & 35 & 46 & 45 & 4.9 \\
\hline $\mathrm{Li}$ & 25 & 36 & 30 & 3.4 \\
\hline $\mathrm{Lu}$ & 0.19 & 0.28 & 0.24 & 1.7 \\
\hline $\mathrm{Mn}$ & 831 & 1133 & 1057 & 2.7 \\
\hline Mo & 1.5 & 2.7 & 2.2 & 4.1 \\
\hline $\mathrm{Nd}$ & 26 & 35 & 34 & 2.8 \\
\hline $\mathrm{Ni}$ & 31 & 60 & 52 & 1.8 \\
\hline $\mathrm{P}$ & 831 & 1133 & 1057 & 2.5 \\
\hline $\mathrm{Pb}$ & 104 & 187 & 142 & 21 \\
\hline $\operatorname{Pr}$ & 7.1 & 11 & 11 & 2.7 \\
\hline $\mathrm{Rb}$ & 103 & 148 & 120 & 3.2 \\
\hline $\mathrm{Sb}$ & 1.8 & $3 \cdot 3$ & 2.7 & 19 \\
\hline $\mathrm{Sm}$ & $5 \cdot 3$ & 7.1 & 6.9 & 2.2 \\
\hline $\mathrm{Sn}$ & 9 & 17 & 14 & 13 \\
\hline $\mathrm{Sr}$ & 73 & 99 & 89 & 0.5 \\
\hline $\mathrm{Tb}$ & 0.64 & 0.83 & 0.81 & 2.5 \\
\hline $\mathrm{Ti}$ & 74 & 111 & 92 & 0.1 \\
\hline $\mathrm{Tl}$ & 0.39 & 0.54 & 0.46 & 1.7 \\
\hline $\mathrm{Tm}$ & 0.21 & 0.31 & 0.27 & 1.9 \\
\hline $\mathrm{U}$ & 3.9 & 5 & 4.7 & 4.9 \\
\hline $\mathrm{V}$ & 65 & 108 & 92 & 1.9 \\
\hline $\mathrm{Yb}$ & 1.3 & 2.0 & 1.8 & 1.7 \\
\hline $\mathrm{Zn}$ & 106 & 145 & 130 & 3.8 \\
\hline $\mathrm{Zr}$ & 4.7 & 13.3 & 9.2 & 0.1 \\
\hline
\end{tabular}

anomalously high amounts of organic matter (TOC and $\mathrm{TN}$ of $17.4 \mathrm{~g} \mathrm{C} \mathrm{kg}^{-1}$ and $1.51 \mathrm{~g} \mathrm{~N} \mathrm{~kg}^{-1}$ in 2004). Freppaz et al. (2013) sampled the surrounding glacial till of the Indren glacier and reported values of TOC and TN of $1.44 \mathrm{~g} \mathrm{C} \mathrm{kg}^{-1}$ and $0.11 \mathrm{~g} \mathrm{~N} \mathrm{~kg}^{-1}$, respectively, an order of magnitude less than the values found on these sediments. The latter were also greater than those observed in recently deglaciated forefields in different alpine and polar regions (Bradley et al. 2014). Conversely, the high levels of total $\mathrm{P}$ and the low proportion of dissolved $\mathrm{P}$ forms were not surprising in a recently deglaciated area, where minerals exposure 
Table 8 Trace elements concentrations and $\mathrm{EF}_{(\mathrm{Ba})}$ in the organic-rich mineral deposits and ice samples (Barbante et al. 2004; Gabrieli 2008) from the Monte Rosa area. $\mathrm{EF}_{(\mathrm{Ba})}$ of trace elements were calculated using normalization for both upper continental crust mean values (column a; Wedepohl 1995) and trace elements concentrations in the Colle Gnifetti ice samples during pre-industrial times (before 1700 AD) (column b).

\begin{tabular}{|c|c|c|c|c|c|c|c|c|c|}
\hline \multirow{3}{*}{$\begin{array}{l}\text { Trace } \\
\text { element }\end{array}$} & \multicolumn{3}{|c|}{ Organic-rich mineral deposit } & \multicolumn{6}{|c|}{ Colle Gnifetti ice core } \\
\hline & \multirow{2}{*}{$\begin{array}{l}\text { Conc. } \\
\left(\mathrm{mg} \mathrm{kg}^{-1}\right)\end{array}$} & \multicolumn{2}{|l|}{$\mathrm{EF}_{(\mathrm{Ba})}$} & \multicolumn{3}{|c|}{ Concentration (ng kg-1) } & \multicolumn{3}{|l|}{$\mathrm{EF}_{(\mathrm{Ba})}$} \\
\hline & & (a) & (b) & Pre-170o & Post-1950 & Post-1970 & Pre-1700 & Post-1950 & Post-1970 \\
\hline $\mathrm{Mn}$ & 1057 & 2.7 & 2.7 & 588 & 2279 & 2039 & 1.1 & 1.2 & 1.1 \\
\hline $\mathrm{Cr}$ & 513 & 7.7 & $5 \cdot 3$ & 144 & $\mathrm{~N} / \mathrm{A}$ & 350 & 1.5 & $\mathrm{~N} / \mathrm{A}$ & 1.1 \\
\hline $\mathrm{Cu}$ & 45 & 3.4 & 1.3 & 53 & 301 & 196 & 2.9 & 4.6 & 3.1 \\
\hline $\mathrm{Zn}$ & 130 & 3.8 & 1.1 & 171 & 4250 & 3494 & 3.6 & 25 & 21 \\
\hline Co & 11.9 & 1.0 & 1.2 & 15 & 32.5 & 33 & 0.8 & 0.5 & 0.5 \\
\hline $\mathrm{Ni}$ & 52 & 1.8 & $3 \cdot 3$ & 24 & N/A & 218 & 0.6 & N/A & 1.5 \\
\hline $\mathrm{Ag}$ & 5.7 & 178 & 25 & 0.34 & $\mathrm{~N} / \mathrm{A}$ & 1.2 & 6.6 & $\mathrm{~N} / \mathrm{A}$ & 6.7 \\
\hline $\mathrm{Cd}$ & 0.2 & 3.9 & 0.1 & $3 \cdot 3$ & 70 & 38 & 45 & 268 & 147 \\
\hline $\mathrm{Bi}$ & 1.7 & 44 & 2.8 & 0.91 & 4.3 & 3.4 & 14 & 19 & 16 \\
\hline $\mathrm{U}$ & 4.7 & 4.9 & 2.8 & 2.5 & 16.8 & 21 & 2.0 & 3.8 & 4.8 \\
\hline $\mathrm{Pb}$ & 142 & 21 & 1.4 & 156 & 3100 & 1929 & 14 & 80 & 51 \\
\hline V & 92 & 1.9 & 6.0 & 23 & 214 & 209 & 0.3 & 0.8 & 0.8 \\
\hline $\mathrm{Ba}$ & 288 & & & 432 & 1525 & 1489 & & & \\
\hline
\end{tabular}

to biotic and abiotic weathering processes is expected to be limited if compared with well-developed, vegetated soils (Wu et al. 2013).

For the origin of these aggregates, several elements can give us indications in this sense. The radiocarbon dating showed that the organic material accumulated was quite old, with a mean age of about 3000 years, suggesting that organic $\mathrm{C}$ may derive either from organic matter that was previously beneath the glacier (Bardgett et al. 2007; Singer et al. 2012) or from aeolian depositions of anthropogenic or natural origin accumulated and processed on the glacier surface. However, the chemical signature of this organic material was typical of microbial remains, as all organic pools showed a $\mathrm{H} / \mathrm{C}$ ratio $>1$ and a $\mathrm{C} / \mathrm{N}$ ratio $<13$ (except NRF), being a first index of a limited presence of the aromatic component (Andreux and Piccolo 1996), such as lignin and phenolic derived compounds, and a relatively high presence of $\mathrm{N}$ residues. Analogous values were reported in recently deglaciated ( $<3 \mathrm{yr}$ ) soils in the Morteratsch proglacial area (Switzerland) (Eckmeier et al. 2013). Interestingly, also in the glacial meltwaters sampled adjacent to the solid deposits, characterized by particularly high DOC levels compared to that reported in other glacial areas (Barker et al. 2006), the DOC Fluorescence Index showed values similar to those reported for microbially derived DOC from lakes in the Antarctic (Mcknight et al. 2001) and in a rock glacier outflow in the Colorado Front Range during late summer and fall (Williams et al. 2007). Taken together, these elements suggest that the organic fraction of the investigated debris is mainly derived from microbial supraglacial or subglacial activity (either fixation of atmospheric $\mathrm{C}$ or processing of aeolian-derived $\mathrm{C}$ sources), excluding a relevant contribution of ancient, recalcitrant organic matter deriving from buried soils or vegetal residues.

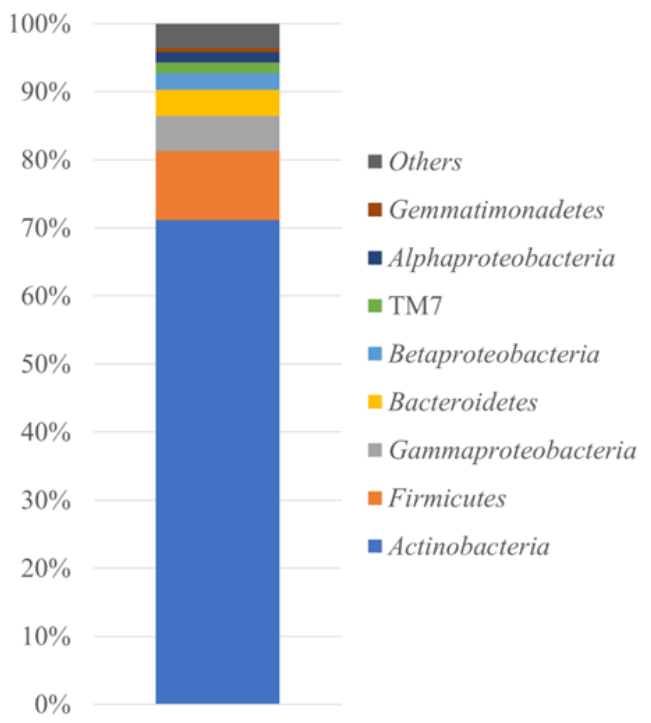

Fig. 5 Relative abundance of the bacterial phyla including $>1 \%$ of total bacterial sequences, with Proteobacteria split in classes. Data refer to a composite sample obtained by pooling DNA from 2004 samples.

The mineral phase within the aggregates was constituted by a large variety of elements. The degree to which these elements were introduced from rock and soil dust or by different sources (anthropogenic 
activity, marine or volcanic emissions, etc.), as assessed by calculating the crustal enrichment factors $\mathrm{EF}_{(\mathrm{Ba})}$, revealed that $\mathrm{Ag}$, $\mathrm{As}, \mathrm{Sn}, \mathrm{Sb}, \mathrm{Pb}$ and $\mathrm{Bi}$, higher than 10, potentially had an allochthonous origin. Sources of these compounds may include regional emissions from adjacent vegetation and soils of different ages but also large-scale emissions, such as Saharan dust, which regularly deposits onto the European Alps (Thevenon et al. 2009; Singer et al. 2012). The $\mathrm{EF}_{(\mathrm{Ba})}$ of the organic-rich mineral deposits were then compared with those measured in ice from Colle Gnifetti, Monte Rosa group ( $2 \mathrm{~km}$ in distance from the Indren Glacier Front), at an altitude of 4450 $\mathrm{m}$ ASL at different reference periods (Table 8, Barbante et al. 2004; Gabrieli 2008). Assuming that the trace element depositions over the Colle Gnifetti ice saddle before the 18th century were totally ascribable to natural sources, we can use them as a reference in the $\mathrm{EF}_{(\mathrm{Ba})}$ calculation, minimizing the bias of the local soil (Table 8; $\mathrm{EF}_{(\mathrm{Ba})}$ column b). A general decrease was observed for the elements, demonstrating that the most part of these elements are derived from ice meltwater without significant external enrichments. The low $\mathrm{EF}_{(\mathrm{Ba})}$ for some heavy metals (e.g., $\mathrm{Cd}, \mathrm{Pb}$, and $\mathrm{Bi}$ ) respect to those of recent ice suggests the major influence of ancient ice melting.

Therefore, we can conclude that both the organic and mineral material constituting the debris object of this study have a glacial origin, although the mechanisms and the dynamics of aggregation of the different fractions are still unclear.

The second question risen by the retrieval of the Indren aggregates was about their potential fate and contribution to the foreland system evolution. Comparing the data collected in 2003 and 2004, the decrease in TOC, CEC and EC indicated that part of the most labile $\mathrm{C}$ forms was lost within the first year of sediment exposure, and that also the cations were scarcely retained by the solid surfaces. However, further analyses showed that in 2004 the fraction of bioavailable C (WEOC) was only limited, and the organic matter characterization confirmed that also the WEOM constituted only a low proportion of the total OM, nonetheless including simple compounds such as aminoacids and saccharide residues, that may offer an easily available energy and macronutrients source for developing microbial communities. Considering $\mathrm{N}$ availability, the analysis of the nitrogen forms highlighted that TDN represented only $2.4 \%$ of the $\mathrm{TN}$, but the most of it were inorganic forms and particularly ammonium, whose concentration showed to be still higher than those commonly reported in recently deglaciated forefields (Schulz et al. 2013). Therefore, we can suppose that such kind of deposits readily act as $\mathrm{C}$ and nutrient sources for the surrounding forefields immediately after their exposure, preserving only a limited ability to provide bioavailable macronutrients after a longer period (in the Indren case, one year). Similar characteristics have been described by Bernasconi et al. (2011) for organic matter found in poorly evoluted soils of the Damma glacier forefield, containing relatively high proportions of labile organic compounds which are easily oxidizable and have an annual to decadal turnover time. However, this does not exclude the potential importance of the studied deposits as organic matter reservoirs, since the establishment of microbial communities able to process the more stable organic material may lead to a long-term release of organic fractions currently unavailable. Although the absence of data on the dissolved $\mathrm{C}$ and $\mathrm{N}$ forms present in the 2003 samples or the impossibility to follow the fate of the deposits for a longer period does not allow us to confirm or reject this hypothesis, these observations suggest that a particular attention should be devoted to similar recently-exposed organic-rich material, taking into account that their chemical composition, and thus their role in the early stages of soil development, may vary upon a short time span.

Focusing on the microbial populations potentially present on the deposits, whose importance in their evolution was discussed above, the qPCR analysis revealed the presence of levels of $16 \mathrm{~S}$ rRNA genes comparable with those previously reported in glacier forefields (Bajerski and Wagner 2013; Liu et al. 2016) and seasonally frozen soils (Gittel et al. 2014; Tripathi et al. 2018). The percentages of microbial $\mathrm{C}$ and $\mathrm{N}$ were also comparable or higher than those found in other recently deglaciated soils (Schulz et al. 2013). All these elements can suggest but not confirm the establishment and development of microbial communities on the debris, although microbial community composition data, particularly those concerning Bacteria, are further in accordance with this interpretation. For instance, the high relative abundance of the phylum Actinobacteria and the orders Sphingobacteriales (Bacteroidetes) and Xanthomonadales (Gammaproteobacteria), coupled with the low percentage of Acidobacteria are coherent 
with a bacterial community associated to a poorly pedogenized or mineral matrix (Nemergut et al. 2007; Franzetti et al. 2013; Mania et al. 2019). In addition, the scarcity of sequences related to bacterial taxa such as Betaproteobacteria (Burkholderiales) and Cyanobacteria, including chemolithoautotrophic and photoautotrophic microorganisms commonly found in supraglacial and subglacial ecosystems (Franzetti et al. 2017; Margesin and Collins 2019) suggests that the picture we obtained, although based on a stable marker molecule such as DNA, is not just representing a relict microbial population, but includes also information on the communities established on the deposits after their deposition and exposure in the forefield. The same reasoning is not valid for Archaea. Indeed, if the dominance of sequences related to Euryarchaeota, and particularly methanogenic Archaea, is a common feature in young soils (Zumsteg et al. 2012), the presence of methanogens has typically been reported in studies on subglacial habitats (Margesin and Collins 2019), from where the genetic material might have been transported.

\section{Conclusions}

Following glacier retreat, organic-rich mineral debris were found among the coarse mineral material present in the glacial foreland Indren area. The organic material, showing a radiocarbon age of about 3000 years and evident features of a microbial origin, is supposed to derive mainly from microbial communities in supraglacial or subglacial ecosystems that cycled and recycled C sources, potentially coming from anthropogenic aeolian depositions. The very limited signs of terrigenous compounds rule out a direct contribution of remnants from preglacial soils. Elemental composition and the crustal enrichment factor of trace elements reveal that the most part of the mineral elements could derive also from ice meltwater, although some elements had an allochthonous origin.

The rapid loss of $\mathrm{C}$ and cations within one year of exposure, suggests that such organo-rich debris may represent a readily available source of $\mathrm{C}$ and nutrients for the forefield system. Moreover, the abundance of bacterial and archaeal marker genes, the levels of microbial $\mathrm{C}$ and the composition of the bacterial microbial community, compatible with those found in young soils, support the view of a microbiota actively involved in the evolution of this organic-rich deposits.

All these elements confirm that such organic-rich deposits of glacial origin may represent "hot spots" suitable for soil formation and plant colonization in recently deglaciated areas, despite leaving several open questions on their formative process and the dynamics of their evolution.

\section{Acknowledgments}

Manuscript writing was supported by the Italian MIUR Project (PRIN 2010-11): "Response of morphoclimatic system dynamics to global changes and related geomorphological hazards" (national coordinator C. Baroni); the contribution of MW Williams was supported by the US NSF-funded Niwot Ridge Long-Term Ecological Research program.

Electronic supplementary material: Supplementary material (Appendixes 1, 2) is available in the online version of this article at https://doi.org/10.1007/s11629-020-6288-8.

Open Access This article is licensed under a Creative Commons Attribution 4.0 International License, which permits use, sharing, adaptation, distribution and reproduction in any medium or format, as long as you give appropriate credit to the original author(s) and the source, provide a link to the Creative Commons licence, and indicate if changes were made. The images or other third party material in this article are included in the article's Creative Commons licence, unless indicated otherwise in a credit line to the material. If material is not included in the article's Creative Commons licence and your intended use is not permitted by statutory regulation or exceeds the permitted use, you will need to obtain permission directly from the copyright holder. To view a copy of this licence, visit http://creativecommons.org/licenses/by/4.0/

Funding: Open access funding provided by Università degli Studi di Torino within the CRUICARE Agreement. 


\section{References}

Agnelli A, Celi L, Corti G, et al. (2002) The changes with depth of humic and fulvic acids extracted from the fine earth and rock fragments of a forest soil. Soil Sci 167: 524-538. https://doi.org/ 10.1097/01.ss.0000026970.27546.f9

Andreux F, Piccolo A (1996) Humus in World Soils. In: Humic Substances in Terrestrial Ecosystems. Elsevier Science B.V.. pp 45-100

Anesio A, Hodson A, Fritz A, et al. (2009) High microbial activity on glaciers: importance to the global carbon cycle. Glob Chang Biol. https://doi.org/10.1111/j.1365-2486.2008.01758.x

Anesio AM, Laybourn-Parry J (2012) Glaciers and ice sheets as a biome. Trends Ecol Evol 27: 219-225. https://doi.org/10.1016/j.tree.2011.09.012

Armando E (2004) Report of the glaciological survey of 2003. Geogr Fis e Din Quat 27 (2): 204.

Bajerski F, Wagner D (2013) Bacterial succession in Antarctic soils of two glacier forefields on Larsemann Hills, East Antarctica. FEMS Microbiol Ecol 85: 128-142. https://doi.org/10.1111/1574-6941.12105

Barbante C, Schwikowski M, Doring T, et al. (2004) Historical record of European emissions of heavy metals to the atmosphere since the 1650 s from Alpine snow/ice cores drilled near Monte Rosa. Environ Sci Technol 38: 4085-4090. https://doi.org/doi.org/10.1021/eso49759r

Bardgett RD, Richter A, Bol R, et al. (2007) Heterotrophic microbial communities use ancient carbon following glacial retreat. Biol Lett 3: 487-490. https://doi.org/10.1098/rsbl.2007.0242

Barker JD, Grottoli AG, Lyons WB (2018) Stable isotope evidence for the biogeochemical transformation of ancient organic matter beneath Suess Glacier, Antarctica. Arctic, Antarct Alp Res 50: 1-7.

https://doi.org/10.1080/15230430.2018.1448643

Barker JD, Sharp MJ, Fitzsimons SJ, et al. (2006) Abundance and dynamics of dissolved organic carbon in glacier systems. Arctic, Antarct Alp Res 38: 163-172. https://doi.org/10.1657/1523o430(2006)38[163:AADODO]2.0.CO;2

Barker JD, Sharp MJ, Turner RJ (2009) Using synchronous fluorescence spectroscopy and principal components analysis to monitor dissolved organic matter dynamics in a glacier system. Hydrol Process 23: 1487-1500. https://doi.org/10.1002/hyp.7274

Beniston M (2004) The 2003 heat wave in Europe: A shape of things to come? An analysis based on Swiss climatological data and model simulations. Geophys Res Lett 31: L02202. https://doi.org/10.1029/2003GL018857

Bernasconi SM, Bauder A, Brunner I, et al. (2011) Chemical and biological gradients along the Damma Glacier soil chronosequence, Switzerland. Vadose Zone J 10: 867-883. https://doi.org/10.2136/vzj2010.0129

Boyd ES, Hamilton TL, Havig JR, et al. (2014) Chemolithotrophic primary production in a subglacial ecosystem. Appl Environ Microbiol 80: 6146-6153. https://doi.org/10.1128/AEM.01956-14

Bradley JA, Singarayer JS, Anesio AM (2014) Microbial community dynamics in the forefield of glaciers. Proc R Soc B 281: 20140882.

https://doi.org/10.1098/rspb.2014.0882

Bremner JM (1965) Inorganic forms of nitrogen. In: Methods of soil analysis: Part 2 - Chemical and Microbiological Properties. American Society of Agronomy, Madison, pp 1179-1237. https://doi.org/10.2134/agronmonogr9.2.c33

Bronk Ramsey C (2009) Bayesian analysis of radiocarbon dates. Radiocarbon 51: 337-360. https://doi.org/10.1017/So033822200033865

Bronk Ramsey C (2001) Development of the radiocarbon calibration program. Radiocarbon 43: 355-363.
https://doi.org/10.1017/Soo33822200038212

Brookes P, Kragt J, Powlson D, et al. (1985) Chloroform fumigation and the release of soil nitrogen: the effect of fumigation time and temperature. Soil Biol Biochem 17: 831835 .

https://doi.org/10.1016/0038-0717(85)90143-9

Brookes P, Powlson D, Jenkinson D (1982) Measurement of microbial biomass phosphorus in soil. Soil Biol Biochem 14: 319-329. https://doi.org/doi:10.1016/0038-0717(82)90001-3

Brooks P, Williams M (1999) Snowpack controls on nitrogen cycling and export in seasonally snow-covered catchments. Hydrol Process 13: 2177-2190.

https://doi.org/10.1002/(SICI)10991085(199910)13:14/15<2177::AID-HYP850>3.0.CO;2-V

Celi L, Schnitzer M, Nègre M (1997) Analysis of carboxyl groups in soil humic acids by a wet chemical method, FourierTransform Infrared spectrophotometry, and solution-state carbon-13 nuclear magnetic resonance. A comparative study. Soil Sci 162: 187-197.

https://doi.org/10.1097/00010694-199703000-00004

Cerli C, Celi L, Kaiser K, et al. (2008) Organic geochemistry changes in humic substances along an age sequence of Norway spruce stands planted on former agricultural land. Org Geochem 39: 1269-1280.

https://doi.org/10.1016/j.orggeochem.2008.06.001

Chen Y, Senesi N, Schnitzer M (1977) Information provided on humic substances by E4/E6 ratios. Soil Sci Soc Am J 41: 352358

https://doi.org/10.2136/sssaj1977.03615995004100020037x

Cocolin L, Alessandria V, Botta C, et al. (2013) $\mathrm{NaOH}$ debittering induces changes in bacterial ecology during table olives fermentation. PLoS ONE 8: e69074.

https://doi.org/10.1371/journal.pone.0069074

Crooke WM, Simpson WE (1971) Determination of ammonium in Kjeldahl digests of crops by an automated procedure. J Sci Food Agric 22: 9-10.

https://doi.org/10.1002/jsfa.2740220104

D'Amico ME, Freppaz M, Filippa G, et al. (2014) Vegetation influence on soil formation rate in a proglacial chronosequence (Lys Glacier, NW Italian Alps). Catena 113: 122-137. https://doi.org/10.1016/j.catena.2013.10.001

D’Amico ME, Freppaz M, Leonelli G, et al. (2015) Early stages of soil development on serpentinite: the proglacial area of the Verra Grande Glacier, Western Italian Alps. J Soils Sediments 15: 1292-1310. https://doi.org/10.1007/s11368-014-0893-5

Dubnick A, Barker J, Sharp M, et al. (2010) Characterization of dissolved organic matter (DOM) from glacial environments using total fluorescence spectroscopy and parallel factor analysis. Ann Glaciol 51: 111-122.

https://doi.org/10.3189/172756411795931912

Dubnick A, Wadham J, Tranter M, et al. (2017) Trickle or treat: The dynamics of nutrient export from polar glaciers. Hydrol Process 31: 1776-1789. https://doi.org/10.1002/hyp.11149

Dümig A, Smittenberg R, Kögel-Knabner I (2011) Concurrent evolution of organic and mineral components during initial soil development after retreat of the Damma glacier, Switzerland. Geoderma 163: 83-94.

https://doi.org/10.1016/j.geoderma.2011.04.006

Eckmeier E, Mavris C, Krebs R, et al. (2013) Black carbon contributes to organic matter in young soils in the Morteratsch proglacial area (Switzerland). Biogeosciences 10: 1265-1274.

https://doi.org/10.5194/bg-10-1265-2013

Fountain AG, Campbell JL, Schuur EAG, et al. (2012) The disappearing cryosphere: impacts and ecosystem responses to 
rapid cryosphere loss. BioScience 62(4): 405-415. https://doi.org/10.1525/bio.2012.62.4.11

Franzetti A, Navarra F, Tagliaferri I, et al. (2017) Potential sources of bacteria colonizing the cryoconite of an Alpine glacier. PLoS ONE 12: e0174786.

https://doi.org/10.1371/journal.pone.0174786

Franzetti A, Tatangelo V, Gandolfi I, et al. (2013) Bacterial community structure on two alpine debris-covered glaciers and biogeography of Polaromonas phylotypes. ISME $\mathrm{J}$ 7: 1483-1492.

https://doi.org/10.1038/ismej.2013.48

Freppaz M, Martin M, Squinobal E, et al. (2013) Water quality, hydrology, and soil properties in a recently deglaciated area (Indren glacier, Valle d'Aosta-NWItaly). In: Mountains Under Watch 2013. Observing climate change effects in the Alps. Forte di Bard (AO). p 54.

Gabrieli J (2008) Trace elements and polycyclic aromatic hydrocarbons (PAHs) in snow and ice sampled at Colle Gniffetti, Monte Rosa (4450 m), during the past 10,000 years: environmental and climatic impications. $\mathrm{PhD}$ thesis, University of Venice.

Gittel A, Bárta J, Kohoutová I, et al. (2014) Site- and horizonspecific patterns of microbial community structure and enzyme activities in permafrost-affected soils of Greenland. Front Microbiol 5: 541. https://doi.org/10.3389/fmicb.2014.00541

Grannas AM, Hockaday WC, Hatcher PG, et al. (2006) New revelations on the nature of organic matter in ice cores. $\mathrm{J}$ Geophys Res Atmos 111: 1-10.

https://doi.org/10.1029/2005JDoo6251

Haeberli W, Frauenfelder R, Kääb A, et al. (2004) Characteristics and potential climatic significance of "miniature ice caps" (crest- and cornice-type low-altitude ice archives). J Glaciol 50: 129-136. https://doi.org/10.3189/172756504781830330

Hoelzle M, Haeberli W, Dischl M, et al. (2003) Secular glacier mass balances derived from cumulative glacier length changes. Glob Planet Change 36: 295-306.

https://doi.org/10.1016/So921-8181(02)00223-0

Hood E, Battin TJ, Fellman J, et al. (2015) Storage and release of organic carbon from glaciers and ice sheets. Nat Geosci 8: 91-96.

https://doi.org/10.1038/ngeo2331

Hood E, Fellman J, Spencer RGM, et al. (2009) Glaciers as a source of ancient and labile organic matter to the marine environment. Nature 462: 1044-1047. https://doi.org/10.1038/nature08580

IUSS Working Group WRB (2006) World reference base for soil resources 2006. Rome.

Jenk TM, Szidat S, Schwikowski M, et al. (2006) Radiocarbon analysis in an Alpine ice core: record of anthropogenic and biogenic contributions to carbonaceous aerosols in the past (1650-1940). Atmos Chem Phys 6: 5381-5390.

https://doi.org/10.5194/acp-6-5381-2006

Kim S, Kramer RW, Hatcher PG (2003) Graphical method for analysis of ultrahigh-resolution broadband mass spectra of natural organic matter, the Van Krevelen diagram. Anal Chem 75: 5336-5344.

https://doi.org/10.1021/ac034415p

King AJ, Meyer AF, Schmidt SK (2008) High levels of microbial biomass and activity in unvegetated tropical and temperate alpine soils. Soil Biol Biochem 40: 2605-2610. https://doi.org/10.1016/j.soilbio.2008.06.026

Kögel-Knabner I, Rumpel C (2018) Advances in molecular approaches for understanding soil organic matter composition, origin, and turnover: a historical overview. Adv Agron 149: 1-48.

https://doi.org/10.1016/bs.agron.2018.01.003

Kuo S (1996) Phosphorus. In: Methods of soil analysis: Part 3 Chemical methods. American Society of Agronomy, Madison, pp 869-919.

https://doi.org/10.2136/sssabookser5.3.c32
Lafrenière MJ, Sharp MJ (2004) The concentration and fluorescence of dissolved organic carbon (DOC in glacial and nonglacial catchments : interpreting hydrological flow routing and DOC sources. Arctic, Antarct Alp Res 36: 156-165. https://doi.org/10.1657/15230430(2004)036[0156:TCAFOD]2.0.CO;2

Lawrence CR, Painter TH, Landry CC, et al. (2010) Contemporary geochemical composition and flux of aeolian dust to the San Juan Mountains , Colorado , United States. J Geophys Res 115: G03007. https://doi.org/10.1029/2009JG001077

Li X, Ding Y, Xu J, et al. (2018) Importance of mountain glaciers as a source of dissolved organic carbon. J Geophys Res Earth Surf 123: 2123-2134. https://doi.org/10.1029/2017JFo04333

Liu J, Kong W, Zhang G, et al. (2016) Diversity and succession of autotrophic microbial community in high-elevation soils along deglaciation chronosequence. FEMS Microbiol Ecol 92: 1-11.

https://doi.org/10.1093/femsec/fiw160

Luterbacher J, Dietrich D, Xoplaki E, et al. (2004) European seasonal and annual temperature variability, trends, and extremes since 1500. Science 303: 1499. https://doi.org/10.1126/science.1093877

Luterbacher J, Werner J, Smerdon J, et al. (2016) European summer temperatures since Roman times. Environ Res Lett 11: 024001. https://doi.org/10.1088/1748-9326/11/2/024001

Maggioni M, Freppaz M, Piccini P, et al. (2009) Snow cover effects on glacier ice surface temperature. Arctic, Antarct Alp Res 41: 323-329. https://doi.org/10.1657/1938-4246-41.3.323

Mania I, D'Amico M, Freppaz M, et al. (2016) Driving factors of soil microbial ecology in alpine, mid-latitude patterned grounds (NW Italian Alps). Biol Fertil Soils 52: 1135-1148. https://doi.org/10.1007/s00374-016-1147-z

Mania I, Gorra R, Colombo N, et al. (2019) Prokaryotic diversity and distribution in different habitats of an alpine rock glacierpond system. Microb Ecol 78: 70-84. https://doi.org/10.1007/s00248-018-1272-3

Margesin R, Collins T (2019) Microbial ecology of the cryosphere (glacial and permafrost habitats): current knowledge. Appl Microbiol Biotechnol 103: 2537-2549. https://doi.org/10.1007/s00253-019-09631-3

Mcknight DM, Boyer EW, Westerhoff PK, et al. (2001) Spectrofluorometric characterization of dissolved organic matter for indication of precursor organic material and aromaticity. Limnol Oceanogr 46: 38-48. https://doi.org/10.4319/lo.2001.46.1.0038

Mladenov N, López-Ramos J, Mcknight DM, et al. (2009) Alpine lake optical properties as sentinels of dust deposition and global change. Limnol Oceanogr 54: 2386-2400. https://doi.org/10.4319/lo.2009.54.6 part 2.2386

Mladenov N, Reche I, Olmo FJ, et al. (2010) Relationships between spectroscopic properties of high-altitude organic aerosols and sun photometry from ground-based remote sensing. J Geophys Res 115: GooF11. https://doi.org/10.1029/2009JGooo991

Mladenov N, Sommaruga R, Morales-Barquero R, et al. (2011) Dust inputs and bacteria influence dissolved organic matter in clear alpine lakes. Nat Commun 2: 405. https://doi.org/10.1038/ncomms1411

Mladenov N, Williams MW, Schmidt SK, et al. (2012) Atmospheric deposition as a source of carbon and nutrients to an alpine catchment of the Colorado Rocky Mountains. Biogeosciences 9: 3337-3355. https://doi.org/10.5194/bg-9-3337-2012

Murphy J, Riley JP (1962) A modified single solution method for the determination of phosphate in natural waters. Anal Chim Acta 27: 31-36.

https://doi.org/10.1016/Sooo3-2670(oo)88444-5

Nemergut DR, Anderson SP, Cleveland CC, et al. (2007) 
Microbial community succession in an unvegetated, recently deglaciated soil. Microb Ecol 53: 110-122.

https://doi.org/10.1007/s00248-006-9144-7

Nikrad MP, Kerkhof LJ, Häggblom MM (2016) The subzero microbiome: microbial activity in frozen and thawing soils. FEMS Microbiol Ecol 92: 1-16. https://doi.org/10.1093/femsec/fiwo81

Ohno T, Zibilske LM (1991) Determination of low concentrations of phosphorus in soil extracts using malachite green. Soil Sci Soc Am J 55: 892-895. https://doi.org/10.2136/sssaj1991.03615995005500030046x

Reimer PJ, Bard E, Bayliss A, et al. (2013) Intcal13 and marine13 radiocarbon age calibration curves $0-50,000$ years cal bp. Radiocarbon 55: 1869-1887. https://doi.org/10.2458/azu_js_rc.55.16947

Ren Z, Martyniuk N, Oleksy IA, et al. (2019) Ecological stoichiometry of the mountain cryosphere. Front Ecol Evol 7: $1-16$.

https://doi.org/10.3389/fevo.2019.00360

Rhoades JD (1983) Cation Exchange Capacity. In: Methods of soil analysis: Part 2 - Chemical and microbiological properties. American Society of Agronomy, Madison, pp 149-157. https://doi.org/10.2134/agronmonogr9.2.2ed.c8

Sarathchandra SU, Perrott KW, Littler RA (1989) Soil microbial biomass: Influence of simulated temperature changes on size, activity and nutrient-content. Soil Biol Biochem 21: 987-993. https://doi.org/10.1016/0038-0717(89)90034-5

Schmidt SK, Nemergut DR, Miller AE, et al. (2009) Microbial activity and diversity during extreme freeze - thaw cycles in periglacial soils, $5400 \mathrm{~m}$ elevation, Cordillera Vilcanota, Perú. Extremophiles 13: 807-816.

https://doi.org/10.1007/s00792-009-0268-9

Schulz S, Brankatschk R, Dümig A, et al. (2013) The role of microorganisms at different stages of ecosystem development for soil formation. Biogeosciences 10: 3983-3996. https://doi.org/10.5194/bg-10-3983-2013

Schurig C, Smittenberg RH, Berger J, et al. (2013) Microbial cell-envelope fragments and the formation of soil organic matter: a case study from a glacier forefield. Biogeochemistry 113: 595-612.

https://doi.org/10.1007/s10533-012-9791-3

Schütz L, Rahn KA (1982) Trace-element concentrations in erodible soils. Atmos Environ 16: 171-176.

https://doi.org/10.1016/0004-6981(82)90324-9

Schütz L, Sebert M (1987) Mineral aerosols and source identification. J Aerosol Sci 18:1-10. https://doi.org/10.1016/0021-8502(87)90002-4

Singer G, Fasching C, Wilhelm L, et al. (2012) Biogeochemically diverse organic matter in Alpine glaciers and its downstream fate. Nat Geosci 5: 710-714.

https://doi.org/10.1038/ngeo1581

Sodano M, Said-Pullicino D, Fiori AF, et al. (2016) Sorption of paddy soil-derived dissolved organic matter on hydrous iron oxide-vermiculite mineral phases. Geoderma 261: 169-177. https://doi.org/10.1016/j.geoderma.2015.07.014

Stubbins A, Hood E, Raymond PA, et al. (2012) Anthropogenic aerosols as a source of ancient dissolved organic matter in glaciers. Nat Geosci 5: 8-11. https://doi.org/10.1038/ngeo1403

Thevenon F, Anselmetti FS, Bernasconi SM, et al. (2009) Mineral dust and elemental black carbon records from an Alpine ice core (Colle Gnifetti glacier) over the last millennium. J Geophys Res 114: D17102. https://doi.org/10.1029/2008JDo11490

Tripathi BM, Kim M, Kim Y, et al. (2018) Variations in bacterial and archaeal communities along depth profiles of Alaskan soil cores. Sci Rep 8: 504. https://doi.org/10.1038/s41598-017-18777-x

Wadham JL, Hawkings JR, Tarasov L, et al. (2019) Ice sheets matter for the global carbon cycle. Nat Commun 10: 3567 . https://doi.org/10.1038/s41467-019-11394-4

Wadham JL, Tranter M, Skidmore M, et al. (2010) Biogeochemical weathering under ice: Size matters. Glob Biogeochem Cycle 24: GB3025. https://doi.org/10.1029/2009GBoo3688

Wedepohl KH (1995) The composition of the continental crust. Geochim Cosmochim Acta 59: 1217-1232.

https://doi.org/10.1016/0016-7037(95)00038-2

Williams BL, Shand CA, Hill M, et al. (1995) A procedure for the simultaneous oxidation of total soluble nitrogen and phosphorus in extracts of fresh and fumigated soils and litters. Commun Soil Sci Plant Anal 26: 91-106.

https://doi.org/10.1080/00103629509369283

Williams BL, Sparling GP (1988) Microbial biomass carbon and readily mineralized nitrogen in peat and forest humus. Soil Biol Biochem 20: 579-581. https://doi.org/10.1016/0038-0717(88)90078-8

Williams MW, Davinroy T, Brooks PD (1997) Organic and inorganic nitrogen pools in talus fields and subtalus water, Green Lakes Valley, Colorado Front Range. Hydrol Process 11: 1747-1760.

https://doi.org/10.1002/(SICI)10991085(19971030)11:13<1747::AID-HYP603>3.0.CO;2-B

Williams MW, Knauf M, Cory R, et al. (2007) Nitrate content and potential microbial signature of rock glacier outflow, Colorado Front Range. Earth Surf Process Landforms 32: 1032-1047. https://doi.org/10.1002/esp.1455

Wu Y, Zhou J, Yu D, et al. (2013) Phosphorus biogeochemical cycle research in mountainous ecosystems. J Mt Sci 10: 43-53. https://doi.org/10.1007/s11629-013-2386-1

Zumsteg A, Luster J, Göransson H, et al. (2012) Bacterial, archaeal and fungal succession in the forefield of a receding glacier. Microb Ecol 63: 552-564. https://doi.org/10.1007/s00248-011-9991-8 